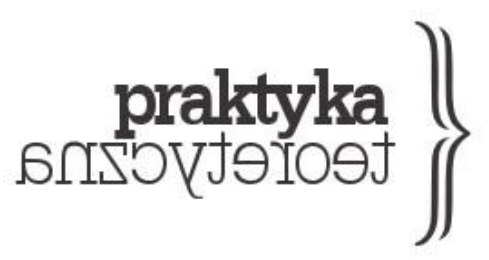

Praktyka Teoretyczna

Numer 2(32)/2019

ISSN 2081-8130

DOI: $10.14746 /$ prt.2019.2.2 www.praktykateoretyczna.pl

\title{
MANIFEST SZTUKI OPIEKI
}

\author{
MieRLE LADERMAN UKELES
}

\begin{abstract}
Abstrakt: Niniejsza publikacja składa się z trzech części. Najstarsza i najważniejsza to artystyczny manifest Mierle Laderman Ukeles Sqtuka opieki [Maintenance Art] z 1969 roku, w którym autorka podejmuje problem wykluczenia w jego różnych postaciach: kobiet ze świata sztuki, prac reprodukcyjnych i opiekuńczych z obszaru pracy etc. Poprzedza go „Wstęp artystki” z 2014 roku, gdzie opisuje ona przeprowadzone w latach siedemdziesiątych projekty artystyczne - swoje rezydencje w Wydziale Oczyszczania Miasta Nowy Jork. Całość otwiera „Wprowadzenie” tłumaczki, sytuujące ten manifest w szerszym, teoretycznopolitycznym kontekście.
\end{abstract}

Słowa kluczowe: feminizm, praca reprodukcyjna, opieka, sztuka publiczna, sztuka feministyczna. 


\section{Wstęp tłumaczki}

Niniejszy tekst to założycielski manifest sztuki opieki - feministyczny głos z pola sztuki awangardowej w sprawie rewolucyjnego zniesienia patriarchalnego podziału na opłacaną, szanowaną i uznawaną pracę „wartościową" oraz pracę nieceniona, nieopłacaną i niewidzialną. Moim zdaniem nie można czytać tego tekstu tylko jako próby dowartościowania opieki albo wyłącznie jako feministycznego manifestu artystycznego. Manifest Ukeles wprowadza, trzydzieści lat przed pojawieniem się teorii intersekcjonalnej, właściwe jej postulaty łącznego, wieloaspektowego postrzegania różnych form opresji. Wyrażone w latach osiemdziesiątych przez czarne feministki problemy niespójności instytucjonalnych systemów opieki społecznej i antydyskryminacji antycypowane były właśnie w Maniféście Ukeles. Należy przy tym zaznaczyć, że artystka nie podjęła wprost kwestii podziałów rasowych, kluczowych dla bell hooks w jej Teorii feministycznej z roku 1984 (wydanie polskie 2013) czy Kimberlé Crenshaw, która skupiała się tym problemie w przełomowym artykule Demarginalizing the Intersection of Race and Sex z 1989 roku.

Ukeles zaproponowała łączną artykulację szeregu problemów, w tym zwłaszcza: wykluczenia kobiet i pracy opieki poza obszar pracy uznanej w kulturze; marginalizacji kobiet w obszarze sztuki; utrzymywania pracownic i pracowników opieki poza obszarem widzialności. Te kwestie łączy nie tylko wykluczenie z patriarchalnej cyrkulacji uznania, ale również ich „słaby”, poddańczo-służebny charakter oraz tendencje do budowania oporu w walce, oporu, którego punktem wyjścia zawsze jest opresja. Ten klasyczny już przynajmniej z perspektywy nakreślonej przez Benjamina - słaby, potoczny początek oraz zahaczenie o brudny i prozaiczny konkret (pamiętamy z Hegla i od Brechta: „Prawda jest konkretna"), sytuuje sztukę Ukeles w obszarze jeśli nie dialektyki, to przynajmniej formułowania „żądania”, roszczenia do ważności, tych, których dotąd publicznie uznawano za nieistniejących.

Prace reprodukcyjne, praca opieki oraz obecność kobiet w sztuce to tylko niektóre formy wykluczenia i opresji. To właśnie w ich obszarze powstają sojusze słabych, wykluczonych i niewidzialnych, akcentujące sprawczość nieobecną w klasycznej, politycznej czy filozoficznej analizie: nieheroiczne działanie słabych. Manifest Ukeles proponuje spojrzenie na tę sprawczość z pola sztuki. W kolejnych latach po publikacji zainspirowało ono nie tylko artystki, ale również teoretyczki i teoretyków, do zmiany postrzegania i praktyki oporu. 
Pierwsze wydanie polskiego przekładu tekstu ukazało się w: F. Malzacher i in. (red), Prawda jest konkretna. Artystycz̨ne strategie w polityce, Fundacja Bęc Zmiana, Warszawa 2016; podstawa przekładu było wydanie w tomie F. Malzacher et al (eds), Truth is Concrete. A Handbook for Artistic Strategies in Real Politics, Sternberg Press, Berlin, 2014. Serdecznie dziękujemy wydawczyni polskiej wersji książki, Bognie Świątkowskiej (Fundacja Bęc Zmiana) oraz redaktorowi tomu, Florianowi Malzacherowi, za zgodę na przedruk polskiej wersji tego tekstu. Publikowany tutaj przekład został poddany minimalnym zmianom redaktorskim.

\section{Wstęp autorki (2014)}

W wyniku pierwszego kryzysu naftowego tysiące ludzi straciło w Nowym Jorku pracę. Władze miasta dążyły do prywatyzacji usług publicznych, w tym wydziału zarządzania odpadami. Sądziłam, że jest to zmiana na gorsze, bo tego typu usługi powinny być kontrolowane przez miasto. Prawdopodobnie z powodu panującego kryzysu moja aplikacja o rezydencje artystyczną w nowojorskim Wydziale Oczyszczania Miasta została przyjęta w 1977 roku. Może pomyśleli: skoro wszystko idzie tak źle, jaką szkodę może nam w tym bałaganie wyrządzić jedna artystka? Touch Sanitation (Oczyszczanie Dotyku/ Czyszczenie przez Dotyk/ Dotyk Czyszczenia, 1979-1980), pierwsze dzieło, jakie zrealizowałam podczas mojej rezydencji, polegało na uściśnięciu dłoni każdej i każdego z ponad 8,5 tysiąca pracownic i pracowników zajmujących się oczyszczaniem miasta oraz mówieniu: „Dziękuję, że utrzymuje Pani/Pan Nowy Jork przy życiu”.

Nie chodziło po prostu o to, by wejść, szybko zrobić to, co miałam do zrobienia, i wyjść. Praca zajęła mi półtora roku i miała na ludzi naprawdę ogromny wpływ. Poszłam do każdego miejsca w tym ogromnym mieście. Po pierwsze ludzie nagle zdali sobie sprawę z tego, że można. Nie zabiło mnie to. Było wspaniale, ciężko, ale dałam radę. Niesamowite jest to, że jedna osoba może dokonać takiego ludzkiego zmapowania systemu; spowodowało to, że sam system zaczął być postrzegany jako ludzki. Bez tego jego pracownicy i pracownice pozostają niewidzialną masa. Osoby zajmujące się sztuką opieki są przez większość czasu niewidzialne. Było dla mnie jasne, że jest to dzieło sztuki. „Chcę uścisnąć Pani/Panu dłoń i podziękować, ale nie musi Pani/Pan w tym uczestniczyć”. Trzy osoby z 8,5 tysiąca odmówiły udziału. Zawsze spędzałam cały dzień z jedną brygada pracownic i pracowników. 
Oczywiście rzecz nie polegała wyłącznie na uścisku dłoni i powiedzeniu „do widzenia” tak właśnie robi wiele polityczek i wielu polityków. Ja przeszłam z nimi wiele kilometrów. Było dla mnie bardzo ważne, by nie ograniczać się do mówienia: „Dzięki, że zbiera Pani/Pan moje śmieci”, ale by właśnie powiedzieć: „Dziękuję, że utrzymuje Pani/Pan to miasto przy życiu”. Bo właśnie to robią. Chciałam też powiązać ich z życiem. Miałam bardzo mocne poczucie, że to miasto jest żywe i mogłoby zginać, gdyby nikt się nim nie opiekował.

O ciało też trzeba dbać. Pracownice i pracownicy, których spotkałam, świetnie zdawali sobie z tego sprawę; starałam się poprzez medialny przekaz o moim projekcie upowszechnić tę wiedzę wśród szerszej publiczności. Ten projekt był dla mnie bardzo ważny także z powodów osobistych. W 1968 roku zostałam matką - stałam się pracownicą opieki i wsparcia. Z powodu wykonywania powtarzalnych czynności, które się z tym wiąża, miałam poczucie wykluczenia z religii „bycia wolnym artystą czy artystką”. Czułam się tak, jakbym miała nigdy nie odzyskać swojej sprawczości dopóty, dopóki wszystkie zajmujące się opieką osoby w ogólnym, miejskim wymiarze również jej nie odzyskaja. Nie jest to możliwe na poziomie indywidualnym. My - jest w tym jakieś „my” - musimy to osiagnąć, działając razem. Właśnie dlatego podjęłam próbę zbudowania takiej koalicji. Zawsze rozmawialiśmy o rewolucji, o zmienianiu społeczeństwa poprzez sztukę. Czułam, że gdyby praca całego muzeum koncentrowała się na trosce o innych, opiece nad społeczeństwem, dbaniu o Ziemię - ludzie postrzegaliby to zagadnienie inaczej. Czułam, że muzeum mogłoby stać się poręczną, praktyczną instytucją wspierającą tę ogromną zmianę - że mogłoby stać się laickim kościołem zajmującym się życiem i śmiercią. Czułam, że byłoby to na tyle ważne, że powinno stać się tam, dokąd każdy może po prostu przyjść i dokonać konwersji! Świat także dzięki temu stałby się innym miejscem. Właśnie to mnie spotkało. Gdzie znalazłam wiarę, że coś takiego mogłoby mieć miejsce w muzeum? Nie wiem. 


\section{Manifest sztuki opieki (1969)}

Projekt wystawy Opieka

I. IDEE

A. Instynkt Śmierci i Instynkt Życia:

Instynkt Śmierci: separacja, indywidualność; Awangarda par excellence; podążanie własną drogą ku śmierci - robienie swojego; dynamiczna zmiana.

Instynkt Życia: połączenie; wieczny powrót; uwiecznienie i OPIEKOWANIE SIE gatunkami; przetrwanie systemów i operacji, equilibrium.

B. Dwa podstawowe systemy: Rozwój i Opieka. Szkopuł każdej rewolucji: kto sprzątnie śmieci w poniedziałek po zakończeniu przewrotu?

Rozwój: tworzenie całkowicie indywidualne; nowość; zmiana; postęp; ekscytacja, odlot lub ucieczka.

Opieka: dbaj o to, by na indywidualnym tworzeniu nie osiadał kurz; chroń nowość; wspieraj zmianę; chroń postęp; broń i przedłużaj rozwój; odnawiaj ekscytację; powtarzaj odlot.

Pokaż swoja pracę - pokaż ją znowu, pilnuj, by muzeum sztuki współczesnej było żywe pilnuj, by domowe ogniska nie przestawały płonać.

Systemy Rozwoju są po części systemami feedbacku z przewaga przestrzeni dla zmiany. Systemy Opieki są bezpośrednio systemami feedbacku z mała przestrzenią na zakłócenia.

C. Opieka jest przekleństwem, pochłania cały pieprzony czas (dosł.). Umysł wytrzeszcza oczy i paruje na widok nudy. 
Kultura przyznaje pracom polegającym na opiece bardzo niski status $=$ minimalne płace; a gospodynie domowe $=$ zero wynagrodzenia .

Sprzątnij biurko, umyj naczynia, wyczyść podłogę, zrób pranie, umyj nogi, zmień dziecku pieluchę, dokończ raport, zrób korektę, napraw płot, dbaj o szczęście klienta, wywal śmierdzące śmieci, uważaj, nie wsadzaj tego do nosa, w co mam się ubrać, nie mam skarpetek, zapłać rachunki, nie śmieć, lina ratunkowa, umyj włosy, zmień pościel, idź do sklepu, skończyły mi się perfumy, powtórz - on nie rozumie, zamknij to jeszcze raz - przecieka, idź do pracy, ta sztuka jest nieciekawa, sprzątnij stół, znowu do niego zadzwoń, spuść wodę, pozostań młoda.

D. Sztuka:

Wszystko, co nazywam Sztuką, jest Sztuką.

Wszystko, co robię, jest Sztuka, jest Sztuką.

„Nie mamy Sztuki, wszystko staramy się robić dobrze” (powiedzenie balijskie).

Sztuka awangardowa, która zakłada bezwzględny rozwój, jest splamiona ideami opieki, aktywnościami właściwymi opiece i działaniami typowymi dla opieki. Sztuka konceptualna i sztuka procesu w szczególności, mimo że opowiadają się za czystym rozwojem i zmianą, w gruncie rzeczy posługuja się niemal wyłącznie strategiami opieki.

E. Wystawa Sztuki Opieki, tytuł: „Opieka wyzeruje wszystko do czystego opiekowania się, które zostanie zaprezentowane jako sztuka współczesna, i nada tym kwestiom jasność poprzez ich ostre przeciwstawienie".

\section{WYSTAWA SZTUKI OPIEKI: OPIEKA}


Trzy części: Opieka Osobista, Ogólna i nad Ziemią.

A. Część pierwsza - Osobista:

Jestem artystką. Jestem kobietą. Jestem żoną. Jestem matką. (Kolejność przypadkowa). Cholernie dużo zmywam, sprzątam, gotuję, odnawiam, daję wsparcie, ochronę itd. Również, jak dotąd niezależnie od wyżej wymienionych, „robię” Sztukę. Teraz będę po prostu robiła te wszystkie codzienne prace opiekuńcze i dopuszczała je do świadomości, wystawiała je jako Sztukę. Będę żyła w muzeum, czasem również z mężem i dzieckiem, przez cały czas trwania wystawy. (Co nie? Albo, jak nie będziecie chcieli, żebym się tu szwendała po nocy, moge po prostu codziennie tu przychodzić). Będę zamiatała i woskowała podłogi, wszędzie odkurzała, myła ściany (czyli wykonywała „obrazy podłogowe, obrazy kurzowe, rzeźby z mydła, obrazy ścienne”), gotowała, zapraszała ludzi na posiłki, będę gromadziła i rozdysponowywała wszelkie odpady funkcjonalne. Wszystko to będzie się odbywało w ramach działania z obszaru sztuki publicznej.

Przestrzeń wystawy będzie może sprawiała wrażenie „wolnej” od sztuki, ale będzie otwarta dla zwiedzających.

\section{MOJA PRACA STANIE SIE DZIEŁEM SZTUKI.}

B. Część druga - Ogólna:

Każdy wykonuje mnóstwo manualnych prac opiekuńczych. Ogólna część wystawy będzie więc złożona z dwóch typów wywiadów:

1. Dotychczas wykonane wywiady indywidualne, przepisane i wystawione.

Rozmówcy pochodzą z około 50 grup społecznych i typów zawodów, obejmujących następujące typy osób: „facet” od napraw, służący, sprzątacz, listonosz, „facet” ze związków zawodowych, budowlaniec, bibliotekarz, „facet” z warzywniaka, 
pielęgniarka, lekarz, nauczycielka, dyrektor muzeum, bejsbolista, sprzedawca, dziecko, kryminalista, prezes banku, prezydent miasta, gwiazda filmowa, artysta etc.

Tematy wywiadów:

- czym jest twoim zdaniem opieka?

- jak czujesz się z tym, ile czasu poświęcasz na prace związane z opieką?

- jaka jest relacja między opieką i wolnością?

- jaka jest relacja między opieką i życiowymi marzeniami?

2. Pokój, w którym prowadzone są wywiady ze zwiedzającymi wystawę:

W pokoju z krzesłami i biurkami ankieterzy będą rozmawiali z widzami wystawy, zadając te same pytania, które postawiono wcześniej. Odpowiedzi powinny mieć charakter osobisty. Wywiady te będą nagrywane i prezentowane w czasie trwania wystawy.

C. Część trzecia - Opiekowanie się Ziemią:

Do muzeum codziennie dostarczane będą kontenery z odpadami następujących rodzajów:

- zawartość jednego kontenera odpadów sanitarnych;

- kontener zanieczyszczonego powietrza;

- kontener zanieczyszczonej wody z rzeki Hudson;

- kontener wyjałowionej ziemi.

Kiedy już kontenery znajdą się na wystawie, każdy będzie obsługiwany: czyszczony, oczyszczany, poddany rehabilitacji, recyklingowi i konserwowany za pomocą różnych technicznych (i/lub pseudotechnicznych) procedur albo przeze mnie, albo przez naukowców. Te procedury serwisowania będa powtarzane przez cały czas trwania wystawy. 
Mierle Laderman Ukeles (Stany Zjednoczone) jest artystką konceptualną. Mieszka w Nowym Jorku. W swoim manifeście Maintenance Art - Proposal for an Exhibition (Sztuka opieki - propozycje wystawy, 1969) stwierdza, że każda praca opieki jest sztuką, od bardzo osobistej, która wiąże się z byciem matką czy prowadzeniem domu, przez prace związane z oczyszczaniem miasta, aż po opiekę nad Ziemią. Od 1977 roku Ukeles była nieopłacaną rezydentką Wydziału Oczyszczania Miasta w Nowym Jorku, gdzie zrealizowała kilka wieloletnich projektów.

Cytowanie: Ukeles, Mierle Laderman. 2019. „Manifest sztuki opieki.” Praktyka Teoretyczna 2(32): $37-45$

DOI: $10.14746 /$ prt.2019.2.2

AUTHOR: Mierle Laderman Ukeles

TITLE: Manifesto for maintenance art

ABSTRACT: This publication has three parts. The oldest and most important is the manifesto Maintenance Art by Mierle Laderman Ukeles from 1969, in which she discusses the problem of social exclusion in its multiple forms, i.e. exclusion of women from the art world; exclusion of reproductive and care labor etc. It is preceded by the Artist's Introduction from 2014, where she discusses her artwork from the 1970s, conducted in the New York City Department of Sanitation and the Introduction by the Translator, situating the Manifesto and subsequent artistic practice in the theoretical and political context.

KEYWORDS: feminism, reproductive labor, care, public art, feminist art. 